\title{
Soil physical indicators of management systems in traditional agricultural areas under manure application
}

\author{
Luiz Paulo Rauber ${ }^{1 *}$, Andréia Patrícia Andrade ${ }^{1}$, Augusto Friederichs ${ }^{1}$, Álvaro Luiz Mafra ${ }^{1}$, Dilmar Baretta², Márcio Gonçalves da Rosa ${ }^{1}$, \\ Maria Sueli Heberle Mafra ${ }^{1}$, Juliano Corulli Correa ${ }^{3}$
}

${ }^{1}$ Santa Catarina State University/CAV, Av. Luiz de Camões, 2090 - 88520-000 - Lages, SC - Brazil.

${ }^{2}$ Santa Catarina State University/CEO, R. Beloni Trombeta

Zanin, 680E - 89815-630 - Chapecó, SC - Brazil.

${ }^{3}$ Embrapa Swine and Poultry, BR-153, km 110 - 89715-899

- Concórdia, SC - Brazil.

*Corresponding author <sr_roiber@yahoo.com.br>

Edited by: Silvia del Carmen Imhoff

Received November 10, 2016

Accepted April 03, 2017
ABSTRACT: Studies of the successive application of manure as fertilizer and its combined effect with long-term soil management systems are important to the identification of the interdependence of physical attributes. The aim of this study was to evaluate changes in the physical properties of a Rhodic Kandiudox under management systems employing successive applications of pig slurry and poultry litter, and select physical indicators that distinguish these systems using canonical discriminant analysis (CDA). The systems consisting of treatments including land use, management and the application time of organic fertilizers are described as follows: silage maize under no-tillage (NT-M7 years); silage maize under conventional tillage (CT-M20 years); annual pasture with chisel plowing (CP-P3 years); annual pasture with chisel plowing (CP-P15 years); perennial pasture without tillage (NT-PP20 years); and no-tillage yerba mate (NT-YM20 years) and were compared with native forest (NF) and native pasture (NP). Soil samples were collected from the layers at the following depths: 0.0-0.05, 0.05-0.10, and 0.10-0.20 m, and were analyzed for bulk density, porosity, aggregation, flocculation, penetration resistance, water availability and total clay content. Canonical discriminant analysis was an important tool in the study of physical indicators of soil quality. Organic fertilization, along with soil management, influences soil structure and its porosity. Total porosity was the most important physical property in the distinction of areas with management systems and application times of manure for the 0.0-0.05 and 0.10-0.20 m layers. Soil aeration and micropores differentiated areas in the 0.05$0.10 \mathrm{~m}$ layer. Animal trampling and machinery traffic were the main factors inducing compaction of this clayey soil.

Keywords: crop system, organic fertilization, soil quality

\section{Introduction}

One focus of research addressing soil physical quality is the identification of sensitive indicators for the analysis of different management systems employed (Zhao et al., 2009). Appropriate management systems and the continuous application of organic fertilizers are expected to improve soil physical properties (Watteau et al., 2012).

Numerous studies in the literature report the effects of soil management systems on physical properties, but few studies have tested repeated applications of organic fertilizers and their combined effects under different soil management systems over a long period. This is particularly important in the western region of Santa Catarina, Brazil, characterized by small farms with subsistence farming in hilly areas, where grain crops are produced in the same space as swine and poultry. In this region, animal husbandry is well known for its high production and productivity levels, with a longstanding tradition of using animal waste as fertilizers in agricultural soils, often combined with the cultivation of silage maize, because of the expansion of dairy farming in the same region.

Another noteworthy aspect of the agriculture in this region is the potential impact of the harvesting of silage maize, animal trampling and mechanical soil tillage at pasture implantation on the physical quality of clayey soils, aside from the influence of forage species and manure reincorporated into the soil, which are factors that impact the soil structure and other mechanical and water properties (Barbosa et al., 2015).

These changes in soil structure are often reflected independently by the different properties, but when the variables are treated and analyzed separately, the classical statistical models often lose sensitivity in the assessment process, especially in a non-randomized experiment design. In this case, multivariate analysis can identify the interaction between the different properties allowing for a simultaneous analysis of their relationships. CDA describes the differences between treatments, deepening the understanding of the relationships between all properties studied in each treatment and can thus select the soil quality indicators (Cruz-Castillo et al., 1994).

Manure application in traditional agricultural areas under different use, tillage and cattle trampling for a long time can improve soil physical properties and multivariate statistical analysis can identify indications of structure recovery and compaction alleviation of these clayey soils. The purpose of this study was to evaluate changes in soil physical properties resulting from different management systems on a Rhodic Kandiudox after successive applications of pig slurry and poultry litter, and select the best soil physical indicators to separate the systems by canonical discriminant analysis (CDA). 


\section{Materials and Methods}

\section{Description of experiments}

The study was conducted in Concordia, SC, Brazil (51 $59^{\prime} \mathrm{W} ; 27^{\circ} 18^{\prime} \mathrm{S}$; $550 \mathrm{~m}$ a.s.1), on a Rhodic Kandiudox, equivalent to an Oxisol according to USDA Soil Taxonomy (1999), under a mesothermal humid subtropical climate (Cfa), according to the Köppen classification, with rainfall evenly distributed throughout the year.

The land use systems consisted of eight study areas with different forms of soil management and application of organic fertilizer based on pig slurry (PS) and poultry litter (PL) (Table 1), without mineral fertilizer application, silage maize under no-tillage and manurefertilized for 7 years (NT-M7 years); silage maize under conventional tillage and manure-fertilized for 20 years (CT-M20 years); annual pasture with chisel plowing and manure-fertilized for 3 years (CP-P3 years); annual pasture with chisel plowing manure-fertilized for 15 years (CP-P15 years); no-tillage with permanent pasture and manure-fertilized for 20 years (NT-PP20 years); no-tillage with yerba mate manure-fertilized for 20 years (NTYM20 years); and also both native forest (NF) and native pasture (NP) used as controls. These areas were selected with similar relief and soil conditions, characterized with regard to the effective depth, color and particle size, in order to have greater consistency and allow for comparisons between them.

The PS was broadcast with a tractor-trailer system on the soil surface. The annual rate was $50 \mathrm{~m}^{3} \mathrm{ha}^{-1}$ based on the official environmental criteria valid at that time. Poultry litter (PL) was applied annually at a rate of $16 \mathrm{~m}^{3} \mathrm{ha}^{-1}$.

\section{Sampling and analyses}

Eight soil samples were systematically collected from two transects per study area (samples collected only once), at points spaced $10 \mathrm{~m}$ apart. The material was sampled from the $0.0-0.05,0.05-0.10$ and $0.10-0.20$ $\mathrm{m}$ layers, in $0.20 \times 0.20 \mathrm{~m}$ trenches. Undisturbed soil samples were collected in stainless steel cylinders (diameter $0.05 \mathrm{~cm}$; height $0.025 \mathrm{~m}$ in the upper two layers, and height $0.05 \mathrm{~m}$ in the deepest layer). From the surroundings of the removed core, samples of soil clods were collected with a spatula and packed in plastic bags to evaluate aggregate stability.

Bulk density (BD) was determined by the volumetric ring method and particle density (PD) by the volumetric flask method. The volume of biopores (Bio) was determined in a sand suction table at $1 \mathrm{kPa}$. The macropores (Macro) were also calculated in sandy sand suction table at $6 \mathrm{kPa}$. Micropores (Micro) were determined from the difference between the total porosity (TP) and Macro. Porosity aeration (AP) was computed as the difference between total pore volume porosity and void volume of pores in a moisture condition of $10 \mathrm{kPa}$. Total porosity (TP) was calculated by the ratio of Ds to Dp. The plant-available water content was estimated by the difference between the water content at a tension of $33 \mathrm{kPa}$ (field capacity) and $1.500 \mathrm{kPa}$ (permanent wilt-

Table 1 - History and description of study areas on a Rhodic Kandiudox under different management systems and application of organic fertilizers.

Land use system and soil management $\quad$ Description

No-tillage maize (NT-M7)

No-tillage maize (Zea mays) for silage (2 growing seasons per year), with 7 years of pig slurry (PS) application every 4 months; ${ }^{3}$ Poultry litter (PL) application (once a year); winter fallow. ${ }^{4}$ Carbon input of $16 \mathrm{Mg} \mathrm{ha}^{-1}$ for 7 years, derived from PS and PL. Area: 4 ha.

Maize under conventional tillage (CT-M20) ${ }^{1}$

Annual pasture with chisel plowing (CP-P3)

Annual pasture with chisel plowing (CP-P15) 1

No-tillage perennial pasture (NT-PP20) ${ }^{1}$

No-tillage yerba mate (NT-YM20) ${ }^{1}$

Native forest (NF)

Native pasture (NP)

${ }^{1}$ Soil liming every 3 years, when required; ${ }^{2}$ Stocking rate: $35-40$ cattle ha-1. ${ }^{3}$ Poultry litter from three production batches of broilers on wood shavings; ${ }^{4} \mathrm{Carbon}$ input via PS (density 1,014g L-1, carbon content $9 \%$ and dry weight $3 \%$ ) and PL (density $290 \mathrm{~g} \mathrm{~L}^{-1}$, carbon content $30 \%$ and dry weight $75 \%$ ), according to data obtained from Scherer et al. (1995). 4 months; ${ }^{3} \mathrm{PL}$ application (once a year); winter ryegrass. ${ }^{4}$ Carbon input of $46 \mathrm{Mg}^{\mathrm{ga}}{ }^{-1}$ for 20 years, derived from PS and PL. Area: 3 ha.

${ }^{2}$ Cultivation of oat (Avena sativa) and ryegrass (Lolium multiflorum) in winter and millet (Pennisetum americanum L.) and sudan grass (Shorghum sudanense L.) in the summer, with annual chisel plowing, with 3 years of PS application every 4 months; ${ }^{3} \mathrm{PL}$ application (once a year). ${ }^{4}$ Carbon input of $6.9 \mathrm{Mg}$ $\mathrm{ha}^{-1}$ for 3 years, from PS and PL. Area: 1 ha.

${ }^{2} 0$ at and ryegrass in winter and millet and sudan grass in the summer, with one annual chisel plowing, 15 years of PS application every 4 months; ${ }^{3} \mathrm{PL}$ application (once a year). ${ }^{4}$ Carbon input $34.5 \mathrm{Mg}$ ha-1 over 15 years, derived from PS and PL. Area: 2 ha.

Pasture of perennial ryegrass, oats and fodder radish (Raphanus sativus) without grazing, with one annual cut (tractor and mowing), with 20 years of PS application; ${ }^{3 P L}$ application (once a year). ${ }^{4}$ Carbon input of $46 \mathrm{Mg} \mathrm{ha}^{-1}$ for 20 years, derived from PS and PL. Area: 1 ha.

Cultivation of yerba mate (llex paraguariensis) and ryegrass between the rows; without grazing, with 20 years of PS application; ${ }^{3} \mathrm{PL}$ application (once a year); both organic fertilizers applied between the rows. ${ }^{4}$ Carbon input of $46 \mathrm{Mg} \mathrm{ha}^{-1}$ for 20 years, derived from PS and PL. Area: 1 ha.

Native forest without human interference.

${ }^{2}$ Native pasture, without application of organic fertilizers of pig and poultry. Area: 2 ha.

Silage maize under conventional tillage (two annual harvests), with 20 years of application of PS every 
ing point). Particle size analysis was conducted by the pipette method and the flocculation degree (FD) was calculated from the amount of water-dispersed clay and total clay (TC) (Embrapa, 2011).

Aggregate stability was determined according to the wet sieving method described by Kemper and Chepil (1965), represented by the mean weight diameter (MWD) of aggregates. Soil penetration resistance was measured in the samples contained in the volumetric rings with balanced moisture at a tension of $6 \mathrm{kPa}$, using a soil penetrometer, with a $3.9 \mathrm{~mm}$ diameter cone, set at an angle of $45^{\circ}$, and penetration speed of $1 \mathrm{~mm} \mathrm{~s}^{-1}$.

Total organic carbon (TOC) content was also evaluated by wet combustion, using potassium dichromate oxidation and was determined by titration, according to the methodology described in Tedesco et al. (1995).

\section{Data analyses}

The data of soil physical properties (bulk density, porosity, macropores, micropores, biopores, aeration porosity, water availability, clay flocculation, mean weight diameter, and penetration resistance) were subjected to CDA to identify the clearest indicators of differences between the sampled areas (Cruz-Castillo et al., 1994) for each layer. In the case of significant difference between the areas, means were compared by CDA of the values of the standardized canonical coefficients (SCC) in the different canonical functions through the LSD test $(p<$ 0.05), as described by Cruz-Castillo et al. (1994). Pearson correlations between total organic carbon content with values for total porosity, micropores and clay flocculation were also calculated $(p<0.05)$. Carbon input was correlated with the above physical properties in the first layer only. Multivariate analyses were performed using the SAS software program, v. 9.1.3.

\section{Results and Discussion}

The relationship between the canonical discriminant function $\mathrm{CDF}_{1}$ and $\mathrm{CDF}_{2}$, i.e., the standardized canonical coefficients (SCC) of the physical properties indicating differences between soil management systems, showed that $\mathrm{CDF}_{1}$ explained $63 \%$ of the total variation while $\mathrm{CDF}_{2}$ explained $21 \%$ in the $0.0-0.05 \mathrm{~m}$ layer (Figure 1A). In the 0.05-0.10 m layer, the canonical correlations $\mathrm{CDF}_{1}$ and $\mathrm{CDF}_{2}$ were 58 and $31 \%$, and 67 and $21 \%$ for the $0.10-0.20$ $\mathrm{m}$ layer, respectively (Figure $1 \mathrm{~B}$ and $\mathrm{C}$ ), which shows that the statistical model used in CDA explained much of the variability in the soil physical properties of these areas. Wilks' Lambda multivariate test indicated highly significant differences $(p<0.001)$ between systems treated with organic fertilization (Figure 1A, B and C).

The LSD test for standardized canonical coefficients (SCC) indicated significant differences $(p<0.05)$ between land use systems for $\mathrm{CDF}_{1}$ as well as for $\mathrm{CDF}_{2}$ (Table 2). In this case, the physical properties were related with the changes in the soil, resulting from the different managements. In the 0.00-0.05 m layer (Table 2), the land use sys-
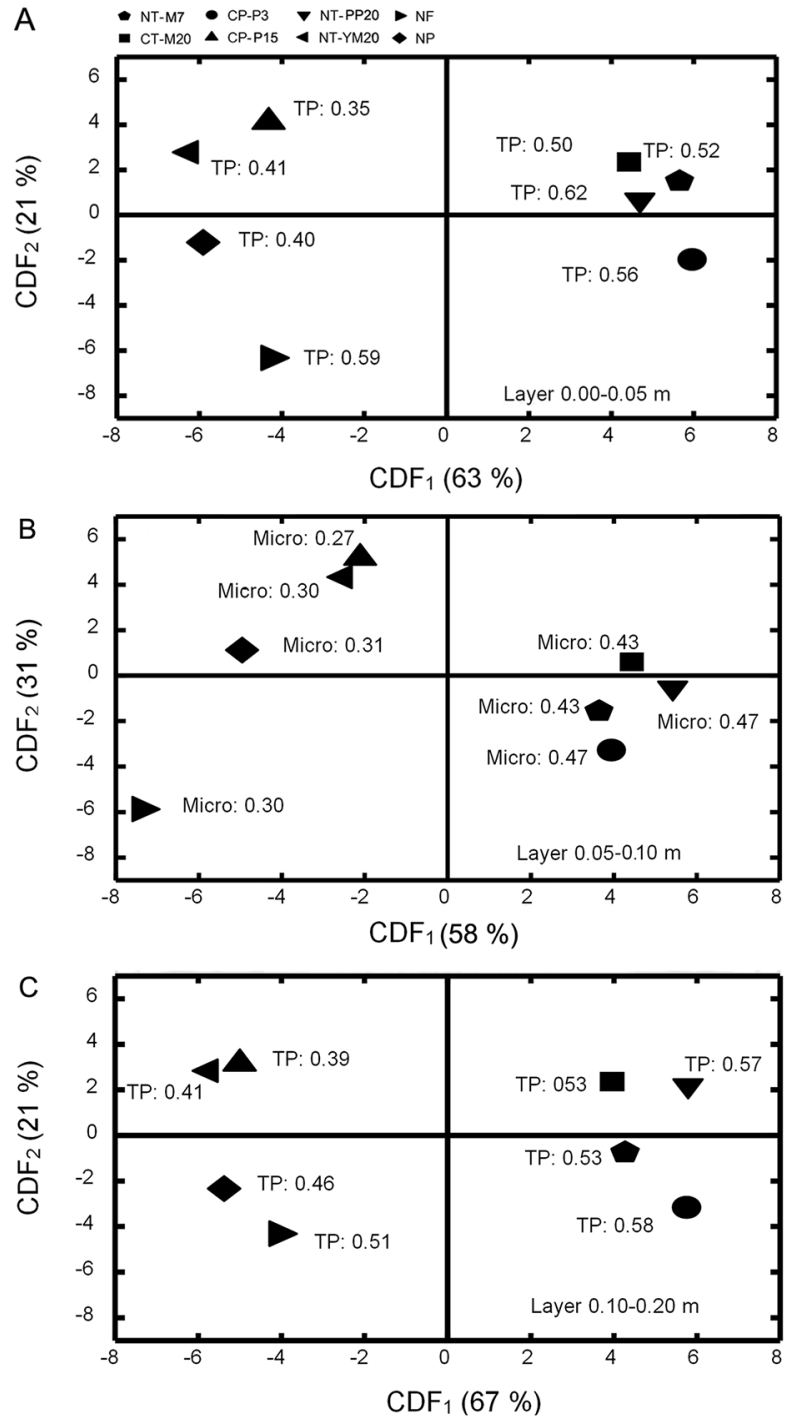

Figure 1 - Relationship between the first and second canonical discriminant function ( $\mathrm{CDF}_{1}$ and $\mathrm{CDF}_{2}$ ) for the means (centroids) of the standardized canonical coefficients (SCC) for the physical properties of a Rhodic Kandiudox, discriminating the different management systems and times of organic fertilization: Silage maize under no-tillage for 7 years (NT-M7), silage maize under conventional tillage for 20 years (CT-M20), annual pasture with chisel plowing for 3 years (CP-P3), annual pasture with chisel plowing for 15 years (CP-P15), perennial pasture without tillage for 20 years (NT-PP20), and no-tillage yerba mate for 20 years (NT-YM20), compared with native forest (NF) and native pasture (NP), in the layers 0.00-0.05 m (A), 0.05-0.10 m (B) and 0.10-0.20 $\mathrm{m}(\mathrm{C})$. Values beside the symbol for the management systems indicate total porosity (TP) in the 0.00-0.05 and 0.10-0.20 m layers and micropores (Micro) in the 0.05-0.10 m layer.

tems CP-P3 and NT-M7 had higher SCC values than the NT-YM20 and CP-P15 areas. The systems CP-P3 and NTM7 were correlated with total porosity (TP) (Table 3). In the 0.05-0.10 m layer, the SCC values in $\mathrm{CDF}_{1}$ were higher 
Table 2 - Test of means comparison of standardized canonical coefficients (SCC), for all soil physical properties analyzed in the first $\left(\mathrm{CDF}_{1}\right)$ and the second canonical discriminant function $\left(\mathrm{CDF}_{2}\right)$ under different management systems with long-term application of pig slurry and poultry litter in the layers $0.00-0.05,0.05-0.10$ and $0.10-0.20 \mathrm{~m}$ in a Rhodic Kandiudox. Mean of 64 replications per layer.

\begin{tabular}{|c|c|c|}
\hline \multirow{2}{*}{ Treatments } & \multicolumn{2}{|c|}{ Standardized canonical coefficient - SCC } \\
\hline & $\mathrm{CDF}_{1}$ & $\mathrm{CDF}_{2}$ \\
\hline \multicolumn{3}{|c|}{$-0.00-0.05 \mathrm{~m}$} \\
\hline NT-M7 & $5.65 \mathrm{ab}$ & $0.85 \mathrm{~cd}$ \\
\hline CT-M2O & $4.42 \mathrm{c}$ & $1.47 \mathrm{c}$ \\
\hline CP-P3 & $5.95 a$ & -1.96 e \\
\hline CP-P15 & $-4.31 d$ & $4.12 \mathrm{a}$ \\
\hline NT-PP20 & $4.69 \mathrm{bc}$ & $0.26 d$ \\
\hline NT-YM20 & -6.23 e & $2.77 b$ \\
\hline NF & $-4.27 d$ & $-6.32 f$ \\
\hline NP & -5.90 e & $-1.21 \mathrm{e}$ \\
\hline \multicolumn{3}{|c|}{$-0.05-0.10 \mathrm{~m}$} \\
\hline NT-M7 & $3.64 b$ & $-1.56 d$ \\
\hline CT-M20 & $4.43 \mathrm{ab}$ & $0.61 \mathrm{~b}$ \\
\hline CP-P3 & $3.94 \mathrm{~b}$ & -3.27 e \\
\hline CP-P15 & $-2.11 c$ & $5.17 \mathrm{a}$ \\
\hline NT-PP20 & $5.42 \mathrm{a}$ & $-0.54 c$ \\
\hline NT-YM20 & $-2.50 c$ & $4.33 \mathrm{a}$ \\
\hline NF & $-7.86 \mathrm{e}$ & $-5.87 f$ \\
\hline NP & $-4.96 d$ & $1.12 \mathrm{~b}$ \\
\hline \multicolumn{3}{|c|}{$-0.10-0.20 \mathrm{~m}$} \\
\hline NT-M7 & $4.26 b$ & $-0.73 b$ \\
\hline CT-M20 & $3.95 b$ & $2.35 \mathrm{a}$ \\
\hline CP-P3 & $5.74 \mathrm{a}$ & $-3.15 c$ \\
\hline CP-P15 & $-4.99 \mathrm{~cd}$ & $3.15 \mathrm{a}$ \\
\hline NT-PP20 & 5.78 a & $2.18 \mathrm{a}$ \\
\hline NT-YM20 & $-5.30 d$ & $2.84 \mathrm{a}$ \\
\hline NF & $-4.07 c$ & $-4.31 d$ \\
\hline NP & $-5.37 d$ & $-2.33 c$ \\
\hline
\end{tabular}

Silage maize under no-tillage for 7 years (NT-M7), silage maize under conventional tillage for 20 years (CT-M20), annual pasture with chisel plowing for 3 years (CP-P3), annual pasture with chisel plowing for 15 years (CP-P15), perennial pasture without tillage for 20 years (NT-PP20), and no-tillage yerba mate for 20 years (NT-YM20), and were compared with native forest (NF) and native pasture (NP). Means followed by the same lower case letter in the columns do not differ from each other by the LSD test $(p>0.05)$.

for NT-PP20 and CT-M20 than the NT-YM20 and CP-P15 systems, indicating a relationship with $\mathrm{TP}$, aeration porosity (AP) and micropores (Micro) (Table 3). Also in the 0.05-0.10 $\mathrm{m}$ layer of $\mathrm{CDF}_{2}$ the land use systems CT-M20 and CP-P15 had higher SCD values (Table 2) than CP-P3, indicating a relation with $\mathrm{TP}$ and total clay (TC) (Table 3). In the deepest layer (0.10-0.20 m), the SCC values (Table 2) were higher in the areas of CP-P3 and NT-PP20, compared to NT-YM20 and CP-P15, with regard to TP (Table 3).

This relationship of soil management systems with porosity was also observed in a study of application of animal waste to the soil, where the pore volume was the most sensitive to changes in soil structure (Khaliq and Abbasi, 2015). These authors applied poultry litter to wheat on coarse-textured soil managed without tillage for three
Table 3 - Coefficient values of parallel discrimination rate (PDR) in the first $\left(\mathrm{CDF}_{1}\right)$ and second $\left(\mathrm{CDF}_{2}\right)$ canonical discriminant function regarding the physical properties of a Rhodic Kandiudox under different management systems and types of organic fertilization of pig slurry and poultry litter.

\begin{tabular}{|c|c|c|}
\hline \multirow{2}{*}{ Variables } & \multicolumn{2}{|c|}{ Parallel discrimination rate - PDR } \\
\hline & $\mathrm{CDF}_{1}$ & $\mathrm{CDF}_{2}$ \\
\hline & \multicolumn{2}{|c|}{$-0.00-0.05 \mathrm{~m}$} \\
\hline Bulk density & 0.12 & 0.00 \\
\hline Total porosity & 0.95 & 0.99 \\
\hline Macropores & -0.02 & 0.04 \\
\hline Micropores & -0.14 & -0.07 \\
\hline Biopores & 0.01 & 0.02 \\
\hline Aeration porosity & 0.04 & -0.70 \\
\hline Water availability & 0.00 & 0.02 \\
\hline Total clay & 0.04 & 0.32 \\
\hline Flocculation degree & 0.00 & 0.38 \\
\hline Mean weight diameter & -0.01 & 0.05 \\
\hline \multirow[t]{2}{*}{ Penetration resistance } & 0.01 & -0.05 \\
\hline & \multicolumn{2}{|c|}{$-0.05-0.10 \mathrm{~m} \longrightarrow$} \\
\hline Bulk density & 0.13 & -0.24 \\
\hline Total porosity & 0.22 & 0.44 \\
\hline Macropores & -0.27 & 0.14 \\
\hline Micropores & 0.41 & 0.09 \\
\hline Biopores & -0.03 & -0.04 \\
\hline Aeration porosity & 0.32 & 0.19 \\
\hline Water availability & -0.02 & -0.01 \\
\hline Total clay & 0.11 & 0.32 \\
\hline Flocculation degree & 0.11 & 0.09 \\
\hline Mean weight diameter & 0.02 & 0.03 \\
\hline \multirow[t]{2}{*}{ Penetration resistance } & 0.00 & -0.01 \\
\hline & \multicolumn{2}{|c|}{$-0.10-0.20 \mathrm{~m}-$} \\
\hline Bulk density & 0.06 & -0.17 \\
\hline Total porosity & 0.99 & -0.16 \\
\hline Macropores & 0.09 & 0.52 \\
\hline Micropores & -0.25 & -0.07 \\
\hline Biopores & 0.02 & 0.00 \\
\hline Aeration porosity & 0.04 & 0.02 \\
\hline Water availability & 0.02 & 0.00 \\
\hline Total clay & 0.02 & 0.40 \\
\hline Flocculation degree & -0.02 & 0.43 \\
\hline Mean weight diameter & 0.03 & 0.04 \\
\hline Penetration resistance & 0.00 & -0.01 \\
\hline
\end{tabular}

years in Pakistan and reported an increase in total porosity and better soil aggregation.

The highest positive values of parallel discrimination rate (PDR) (Table 3) observed in $\mathrm{CDF}_{1}$ indicate the most influential properties in the separation between soil uses. In the 0.00-0.05 m layer, total porosity (TP) had the highest positive value for the PDR coefficient of 0.95 (Table 3). For $\mathrm{CDF}_{2}, \mathrm{TP}$ (0.99), flocculation degree (FD) (0.38) and total clay (TC) (0.32) were the variables that contributed most to the distinction. In the 0.05-0.10 m layer, the PDR values that separated the areas within $\mathrm{CDF}_{1}$ were micropores (Micro) (0.41) and aeration porosity (AP) (0.32), while for $\mathrm{FCD}_{2}$, these values were TP (0.44), and TC (0.32) (Table 3). 
In the $0.10-0.20 \mathrm{~m}$ layer the greatest contributions were from the variables $\mathrm{TP}(0.99)$ in $\mathrm{CDF}_{1}$ and macropores (Macro) (0.52), FD (0.43), and TC (0.40) in $\mathrm{CDF}_{2}$ (Table 2).

In general, similarities were observed between areas in the layers 0.00-0.05 and 0.10-0.20 m (Figure 1A and C), forming two groups, of which the first comprised CP-P3, NT-M7, CT-M20 and NT-PP20, and the second NP, CPP15 and NT-YM20. The NF area used as control, which presented suitable soil structure and water levels for plant growth, differed from the other areas in the three layers in TP (Table 3). One of the main reasons for the degradation of cultivated areas is soil compaction caused by machinery traffic, agricultural implements and animal trampling, affecting the soil structure, altering soil aeration and water infiltration and increasing root penetration resistance, especially in clayey soils (Kutílek et al., 2006), as in the case of the Rhodic Kandiudox under study.

The areas CP-P3, NT-M7, CT-M20, and NT-PP20, presented in the common group of all three layers (Figure $1 \mathrm{~A}, \mathrm{~B}$ and $\mathrm{C}$ ), included different tillage systems and fertilization times, indicating that the influence of soil tillage and the manure application on the soil physical conditions is not decisive. One aspect they have in common is the cultivation of grass species, which are recognized as effective in the formation of stable aggregates, macropores and continuous channels. In NT-PP20 and CP-P3, the effect of the root systems of different forages on the construction of the soil pore system of the pastures may have been decisive. The maize areas CT-M20 and NT-M7 show the possible effect of the crop on the soil structure, due to the direct root action (Bronick and Lal, 2005). The similarity of CP-P3 was greatest between NT-PP20 and NT-M7 in all three layers, due to the absence of animal interference in these areas, preventing the negative effect of trampling on the soil physical quality. The results of the area CP-P3, on the other hand, can be explained by the short period of influence of soil management and animals.

The second group that stands out in the layers 0.00 0.05 and $0.10-0.20 \mathrm{~m}$ (Figure $1 \mathrm{~A}$ and $\mathrm{C}$ ) consisted of the areas with yerba mate (NT-YM20), pasture (CP-P15) and native pasture without manuring (NP). These areas had higher bulk density and penetration resistance, resulting in TP values of $0.41,0.35$ and $0.40 \mathrm{~m}^{3} \mathrm{~m}^{-3}$, respectively. This may be related to the constant presence of animals, which may coincide with conditions of high soil moisture in CP-P15 and NP, and the traffic of manure distribution equipment always at the same location, in between the lines of yerba mate that promote surface compaction. Interestingly, the area CP-P15 was in a stage of degradation, evidenced by high values of bulk density and penetration resistance, a result of inefficient management of the area, with the constant presence of dairy cattle and overgrazing. The pressure exerted by machinery traffic and animal trampling causes compaction of the topsoil and changes throughout the pore system, especially when trampling occurs when the water content is favorable to soil compaction, reflected in higher density and penetration resistance as well as decreased porosity (Reichert et al., 2009).
Using organic fertilizer in the supposition that it would improve soil physical properties, Mellek et al. (2010) tested the growth rates of dairy liquid manure in a Cambisol and observed a reduction in bulk density (1.32 to 1.17 $\mathrm{Mg} \mathrm{m}^{-3}$ ) in the 0-05 $\mathrm{m}$ layer and an increase in macroposity and aggregate size. According to the same authors, the reduction in bulk density could be related to organic material influencing soil porosity in the treatments with higher rates of organic residue addition.

The $\mathrm{CDF}_{2}$ explained $31 \%$ of the differences in the 0.05-0.10 m layer (Figure 1B), designating TC and TP as physical indicators for distinguishing the areas (Table 3). The organic compounds derived from pig manure and poultry litter may change the electric potential of the soil surface and cause clay dispersion. When applying pig manure to an Oxisol, Barbosa et al. (2015) observed an increase in aggregate mass $<0.250 \mathrm{~mm}$, which may be explained by the reduced clay flocculation. Thus, longstanding use of organic fertilization can lead to changes in functional groups and colloid reactivity and increase clay dispersion. However, this effect is temporary because these organic compounds are easily degradable.

Changes in the structure of this Rhodic Kandiudox caused by mechanical processes, detected by the separation of areas by canonical discriminant analysis, such as animal trampling or repeated machine traffic, suggest that these influences prevailed over those exerted by organic fertilization. On the other hand, Mellek et al. (2010) studied physical changes after applying animal manure under different soil management systems, and concluded that there was no influence from manure application on soil physical properties. These authors argue that changes in soil physical properties due to manuring may be strongly associated with the long-term soil management of areas and reinforce the idea that the main contribution of animal manure application to the soil physical quality is a resultant increase in organic matter, which, in turn, increases pore volume and reduces bulk density, resulting in improvements in the structure (Oliveira et al., 2015). Rather, there was no direct relationship between organic material input (Table 1) and the physical quality of this clayey soil as expressed by total porosity and micropores, being the clearest indicators for the discriminating systems (no correlation $p>0.05$ ) since there was correlation between porosity and soil TOC. The soil content of organic carbon can be increased by conservation management systems, which include cover crops and the application of organic residues (D'Hose et al., 2014). It should be taken into account that the application of PS and PL can have an indirect effect on soil carbon and, thus, porosity, wherein these residues, which have high concentrations of nutrients essential to plants, may increase root biomass production and growth. The cycling of these materials that are returned to the soil can increase carbon input.

Assessing the influence of the application of pig manure and pig litter after eight years in an Inceptisol under no-tillage, Comin et al. (2013) observed an increase in macroporosity in the $0.00-0.20 \mathrm{~m}$ layer. Changes in physical 
properties of an Oxisol in areas of pasture and soil managed under no-tillage were also observed by Oliveira et al. (2015) in conventional tillage with PS application for more than 20 years. These authors concluded that there had been a reduction in pore volume due to the increase in density and penetration resistance, compared to the control. Veiga et al. (2008) studied the effect of the application of pig, cattle and poultry manure after nine years in a very clayey Kandiudox, tested under conventional tillage, chisel plowing and no-tillage. These authors concluded that tillage increased total porosity and macroporosity, but this effect decreased over time after tilling due to the natural reconsolidation of the soil, while the manures did not affect the physical properties significantly.

In the 0.05-0.10 m layer (Figure 1B), the distinction between the systems with PS and PL application, aside from pasture without manuring and NF can be clearly observed. This separation is evidenced by the highest parallel discrimination rate (PDR) of soil management systems for the micropores. This may be related to the transfer of pressures from animal trampling and machinery traffic from the soil surface to the $0.05-0.10 \mathrm{~m}$ layer, where the management systems reduced macroporosity, indicating sensitivity to the loss of soil physical quality in cultivated areas.

\section{Conclusions}

Canonical discriminant analysis showed that the physical indicators with the highest sensitivity for the distinction of areas in terms of variation in soil management system and time of organic waste application, are related to soil porosity (total porosity and microporosity). In addition, total clay and flocculation degree form a second group of indicators of physical properties for the separation of these systems.

There were no relationships between carbon input and the form of animal manure or time of application of these materials and the physical indicators. Animal trampling and continuous machinery traffic can be identified as the main factors related to compaction of this clayey soil under traditional agricultural use.

\section{References}

Barbosa, G.M.C.; Oliveira, J.F.; Miyazawa, M.; Ruiz, D.B.; Filho, J.T. 2015. Aggregation and clay dispersion of an Oxisol treated with swine and poultry manures. Soil and Tillage Research 146: 279-285.

Bronick, C.J.; Lal, R. 2005. Soil structure and management: a review. Geoderma 124: 3-22.

Comin, J.J.; Loss, A.; Veiga, M.; Guardini, R.; Schmitt, E.; Oliveira, P.A.V.; Belli Filho, P.; Couto, R.R.; Benedet, L.; Muller Júnior, V.; Brunetto, G. 2013. Physical properties and organic carbon content of a Typic Hapludult soil fertilised with pig manure and pig litter in a no-tillage system. Soil Research 51: 459-470.

Cruz-Castillo, J.G.; Ganeshanandam, S.; MacKay, B.R.; Lawes, G.S.; Lawoko, D.J.C.W. 1994. Applications of canonical discriminant analysis in horticultural research. HortScience 29: 1115-1119.
D'Hose, T.; Cougnon, M.; Vliegher, A.; Vandecasteele, B.; Viaene, N.; Cornelis, W.; Bockstaele, E.V.; Reheul, D. 2014. The positive relationship between soil quality and crop production: a case study on the effect of farm compost application. Applied Soil Ecology 75: 189-198.

Empresa Brasileira de Pesquisa Agropecuária [Embrapa]. 2011. Manual of soil analysis methods = Manual de métodos de análise de solo. 2ed. Embrapa, Rio de Janeiro, RJ, Brazil (in Portuguese).

Kemper, W.D.; Chepil, W.S. 1965. Aggregate stability and size distribution. p. 499-510. In: Black, C.A., ed. Methods of soil analysis. American Society of Agronomy, Madison, WI, USA.

Khaliq, A.M.; Abbasi, K. 2015. Improvements in the physical and chemical characteristics of degraded soils supplemented with organic-inorganic amendments in the Himalayan region of Kashmir, Pakistan. Catena 126: 209-219.

Kutílek, M.; Jendele, L.; Panayiotopoulos, K.P. 2006. The influence of uniaxial compression upon pore size distribution in bi-modal soils. Soil and Tillage Research 86: 27-37.

Mellek, J.E.; Dieckow, J.; Silva, V.L.; Faveretto, N.; Pauletti, V.; Vezzani, F.M.; Souza, J.L.M. 2010. Dairy liquid manure and notillage: physical and hydraulic properties and carbon stocks in a Cambisol of southern Brazil. Soil and Tillage Research 110: 69-76.

Oliveira, D.M.S.; Lima, R.P.; Jan Verburg, E.E. 2015. Physical quality of soil under different systems of tillage and application of pig slurry. Revista Brasileira de Engenharia Agrícola e Ambiental 19: 280-285 (in Portuguese, with abstract in English).

Reichert, J.M.; Suzuki, L.E.A.S.; Reinert, D.J.; Horn, R.; Häkansson, I. 2009. Reference bulk density and critical degree compactness for no-till crop production in subtropical highly weathered soils. Soil and Tillage Research 102: 242-254.

Scherer, E.E.; Baldisserea, I.T.; Dias, L.F.X. 1995. Characterization and evaluation of manure fertilizer potential liquid swine in the western region, Santa Catarina = Caracterização e avaliação do potencial fertilizante do esterco líquido de suínos da região oeste Catarinense. Revista Agropecuária Catarinense 8: 35-39 (in Portuguese).

Soil Survey Staff. 1999. Soil Taxonomy: A Basic System of Soil Classification for Making and Interpreting Soil Surveys. 2ed. USDA-Natural Resources Conservation Service, Washington, DC, USA. (Agriculture Handbook, 436).

Tedesco, M.J.; Gianello, C.; Bissani, C.A.; Bohnen, H.; Volkweiss, S.J. 1995. Analysis of Soil, Plants and Other Materials = Análise de Solo, Plantas e Outros Materiais. 2ed. Editora Universidade Federal do Rio Grande do Sul, Porto Alegre, RS, Brazil (Boletim Técnico, 5) (in Portuguese).

Veiga, M.D.; Reinert, D.J.; Reichert, J.M.; Kaiser, D.R. 2008. Short and long-term effects of tillage systems and nutrient sources on soil physical properties of a southern Brazilian Hapludox. Revista Brasileira de Ciência do Solo 32: 1437-1446.

Watteau, F.; Villemin, G.; Bartoli, F.; Schwartz, C.; Morel, J.L. 2012. $0-20 \mu \mathrm{m}$ aggregate typology based on the nature of aggregative organic materials in a cultivated silty topsoil. Soil Biology and Biochemistry 46: 103-114.

Zhao, Y.; Wang, P.; Li, J.; Chene, Y.; Yingf, X.; Liu, S. 2009. The effects of two organic manures on soil properties and crop yields on a temperate calcareous soil under a wheat-maize cropping system. European Journal of Agronomy 31: 36-42. 